\title{
Genealogies of Resilience: From Conservation to Disaster Adaptation
}

Developed within systems ecology in the 1970s, 'resilience' as a metascience of complex adaptive systems and as an operational strategy of risk management has flourished, progressively asserting itself as a dominant discourse in natural resource management. The concept of resilience has rapidly infiltrated vast areas of the social sciences, becoming a regular, if under-theorised, term of art in discussions of international finance and economic policy, corporate risk analysis, the psychology of trauma, development policy, urban planning, public health, and national security. Since the 1990s, global financial institutions such as the International Monetary Fund, the World Bank, and the Bank for International Settlements have increasingly incorporated strategies of 'resilience' into their logistics of crisis management, financial regulation, and development economics. ${ }^{1}$

This chapter is a rework of an article co-authored with Melinda Cooper. I am grateful for her generous permission to revise it for this book. All the changes are mine alone. Walker, J. \& Cooper, M. (2011). Genealogies of resilience: from systems ecology to the political economy of crisis adaptation. Security Dialogue, $42(2), 143-160$.

${ }^{1}$ Nsouli, S. et al (1995, Dec 1). Resilience and growth through sustained adjustment: the Moroccan experience. IMF Occasional Paper No. 117; World Bank (2006, Apr 27). Social resilience and state fragility in Haiti: a country social analysis. Caribbean Country Management Unit, Latin America and the Caribbean Region Report No. 36069-HT; Bank

(C) The Author(s) 2020

J. Walker, More Heat than Life: The Tangled Roots of Ecology, Energy, and Economics, https://doi.org/10.1007/978-981-15-3936-7_14 
With the post-9/11 revolution in 'homeland security', resilience became a byword among agencies charged with co-ordinating security responses to climate change, critical infrastructure protection, natural disasters, pandemics, and terrorism, reorienting these once distinct policy arenas towards a horizon of critical future events which (we are told) we cannot predict or prevent but merely adapt to by 'building resilience'. ${ }^{2}$ Abstract and malleable enough to encompass the worlds of high finance, defence, urban infrastructure, and the global environment within a single analytic, the concept of resilience has become pervasive in the language of global governance.

This chapter traces the genealogy of 'resilience' from its first formulation in ecosystems science to its recent proliferation across disciplines and policy arenas loosely concerned with the logistics of crisis management, investigating its premises in and generalisation from complex systems theory.

The contemporary usage of the term 'resilience' originated in the work of the ecologist C.S. Holling and retains definitive links to this field. This should direct our attention to the exemplary function of 'ecological risk' within contemporary imaginaries of security, which can increasingly be taken as the foundational context of security in our era of thermal crisis. The success of this ecological concept in colonising multiple arenas of governance can be attributed to its intuitive ideological fit with a neoliberal philosophy of complex adaptive systems, the under-acknowledged legacy of Friedrich Hayek. Where once it was commonly assumed that neoliberalism was of a piece with the neoclassical method of the Chicago school, this crudely positivist current of neoliberalism has increasingly been overtaken in intellectual influence by the mature Austrian philosophy of Hayek. Further, it would appear that the science of complex adaptive systems has become a discursive reference point for the full spectrum of contemporary risk interventions. Whereas energy physics provided a foundational role in modernist theories of economic and ecological organisation, and the homeostatic systems of first-order cybernetics dominated the economic and military sciences of the Cold War, complexity science now

for International Settlements (2008). Basel Committee on banking supervision announces steps to strengthen the resilience of the banking system. Geneva: BIS.

${ }^{2}$ World Bank (2008). Climate resilient cities: a primer on reducing vulnerabilities to climate change impacts and strengthening disaster risk management in East Asian cities. Washington DC: World Bank; UK Cabinet Office (2007). Operations in the UK: the defence contribution to resilience. Joint Doctrine Publication, 2e. 
serves as a source of naturalising metaphors for contemporary practices of security, functioning to neutralise critical inquiry into the disastrous consequences of neoliberal policy in the arenas of financial regulation, urban planning and crisis response, development, environmental management, and climate change.

This conceptual genealogy of 'resilience' first considers Holling's innovations in ecology, and then Hayek's in economics broadly defined. Inspired by very different concerns, Holling and Hayek made profoundly influential contributions to their respective fields, and these have ended up coalescing in uncannily convergent positions. In their writings of the early 1970s, Holling and Hayek were simultaneously preoccupied by questions of the epistemic limits to prediction and assertions of ecological limits to growth. In common is their rejection of metaphors from classical thermodynamics, their early adoption of the lexicon of 'complex adaptive systems', their pessimism about the management of complex systems according to predictive models, and the rejection of the Limits to Growth report as an example of all that was wrong with the image of their respective sciences in the public sphere. Importantly, in their late careers both figures sought to universalise the significance of their projects well beyond the natural/social science boundary. The two perspectives, originally informed by antagonistic concerns, have ended up merging in the contemporary discourse of crisis response through resilience. At stake in this tacit union is a governmental philosophy of nature and society so allencompassing and resilient to critique that the effects of political interventions (and non-interventions) made in its name, no matter how catastrophic, seem as inescapable as the weather.

This chapter argues for the critical importance of the proximity between the emergent discourse of 'resilience' and contemporary neoliberal practices of political management, which is demonstrated through an analysis of the rise of resilience in the specific cases of international finance, critical infrastructure protection, and 'sustainable' development. Returning to the arts of ecological management from which 'resilience' arose, I conclude with a reflection on the evolution of complex ecosystems theory, from critique to collaboration. 


\section{S. Holling's Innovations in Ecology: Origins of Resilience SCIENCE}

The work of the ecologist Crawford 'Buzz' Holling represents a crucial shift in the annals of systems ecology. Holling did some of the most important work in the early 1970s to modernise the classical ecosystems model of ecological dynamics in terms of the new 'complexity science': away from mechanistic assertions of equilibrium typical of post-war cybernetics towards the contemporary 'complexity science' view of ecosystems. In the 1990s, Holling went on to found the consortium of environmental scientists called the Resilience Alliance. More recently, these initiatives have been brought together within the Stockholm Resilience Centre, a highprofile think-tank which promotes the uses of resilience theory in international environment and development projects. What follows is a brief outline of Holling's innovations in applied ecology in the 1970s and his subsequent efforts since the mid-1990s to incorporate 'social systems' and 'economic systems' into a general complexity science of 'socio-ecological resilience'.

Abel and Stepp have described the interface of complexity science with ecology:

[...] what actually constitutes complex systems science is not yet settled. Although there are many threads, we and others [...] see an integrated, evolutionary science of complex systems emerging from the synergy between new computational paradigms (chaos theory, agent-based modelling, and self-organization), dramatic breakthroughs in the venerated field of nonequilibrium thermodynamics, empirical research into large, complicated systems such as weather, earth systems, and ecosystems, and innovation in evolutionary theory. [...] As an emerging field, some researchers claim their part as the whole, but we prefer to see the connections and the possibilities of an open, multi-disciplinary, evolutionary, and integrative systems science. ${ }^{3}$

Whilst a sharp distinction between classical systems ecology and its post-1970s complexity turn effaces much that is continuous in the discipline, the influence of the new complexity science on Holling's school

${ }^{3}$ Abel, T. \& Stepp, J. (2003). A new ecosystems ecology for anthropology. Ecology and Society, 7(3). 
of ecosystem management is profound. ${ }^{4}$ The key image of science that propelled the formalisation of economics (in the 1870s) and ecology (in the 1950s) was of smooth and continuous returns to equilibrium after shock, an image derived from different vintages of classical mechanics, thermodynamics, and systems theory. Holling's widely cited paper 'Resilience and Stability of Ecological Systems' (1973) destabilised the notion of 'equilibrium' as the core of the ecosystem concept and the normal terminus of ecosystem trajectory, signifying a shift amongst ecologists away from the notion that there exists a 'balance of nature' to which life will return eventually if left to self-repair. ${ }^{5}$ Having worked for years in the field as a resource manager and conservation ecologist, Holling began his classic 1973 paper on resilience by noting that:

[...] traditions of analysis in theoretical and empirical ecology have been largely inherited from developments in classical physics and its applied variants $[\ldots]$ there has been a tendency to emphasize the quantitative rather than the qualitative, for it is important in this tradition to know not just that a quantity is larger than another quantity, but precisely how much larger. [...] But this orientation may simply reflect an analytic approach developed in one because it was useful and then transferred to another where it may not be. ${ }^{6}$

Holling went on to distinguish between an existing notion that he calls 'engineering resilience' and his alternative, a properly 'ecological' resilience. Engineering resilience, associated with the mathematical models of the systems ecology of the day, is an abstract variable, simply the time ( $t$ ) it takes a system to return to a stable maximum (or equilibrium position) after a disturbance. The return is simply assumed, and the equilibrium state is taken as equivalent to long-term persistence. ${ }^{7}$ What Holling sought

${ }^{4}$ de Laplante, K. (2005). Is ecosystem management a postmodern science? In K. Cuddington \& B. Beisner (Eds.), Ecological paradigms lost: routes of theory change (pp. 398-416). Amsterdam: Elsevier.

${ }^{5}$ Holling, C. S. (1973). Resilience and stability of ecological systems. Annual Review of Ecology and Systematics (4), 1-23.

${ }^{6}$ Holling (1973, p. 1).

${ }^{7}$ Odum, E. P. (1969). The strategy of ecosystem development. Science, 164 (3877), 262-270; Lewontin, R. (1969). The meaning of stability. In Diversity and stability of ecological systems (pp. 13-24). Brookhaven, NY: Brookhaven Symposia in Biology, vol. 22; May. R. (1973). Complexity and stability in model ecosystems. Princeton, NJ: Princeton University Press. 
rather to define is a complex notion of resilience which might account for the capacity of an ecosystem to remain cohesive even while undergoing extreme perturbations. If stability refers to the familiar notion of a return to equilibrium, 'ecological' resilience designates the complex biotic interactions that determine 'the persistence of relationships within a system': thus resilience is 'a measure of the ability of these systems to absorb changes of state variables, driving variables, and parameters, and still persist'. ${ }^{8}$

Holling pointed to the dangers of the management theory of 'maximum sustained yield' (MSY), long dominant in industrial forestry and fisheries, with its claims to enumerate a fixed quantity of 'surplus' cod or spruce that can be harvested year in year out, without undermining the ability of the ecosystem to regenerate its own reproductivity. Holling's argument here (mirroring Hyman Minsky's post-Keynesian account of financial crises) is that the long-term anticipation of stability may be inherently destabilising. The expectation of a constant yield of (re)productivity may fragilise a natural resource to such an extent that it undermines the complex factors supporting the resilience of the system as a whole: for example, by lowering the average age of an overharvested fish population to a point below sexual maturity. 'The very approach $[\ldots]$ that assures a stable maximum sustained yield of a renewable resource might so change these deterministic conditions that the resilience is lost or reduced so that a chance and rare event that previously could be absorbed can trigger a sudden dramatic change and loss of structural integrity of the system.' Holling's perspective on resource management reflects the emerging critical voices which, in the early 1970s, insisted that intensive methods in agriculture and resource extraction would at some point transgress inherent limits to sustainability, resulting in mass extinctions and intolerable over-pollution. For Holling, the equilibrium approach was dangerous in its abstraction: glossing over the unknowably complex interdependencies of specific landscapes pressed into the conditions of maximised yield, it accelerated the process of fragilisation, leading to the potentially irreversible loss of biodiversity and ecosystem function. The urgent focus for the conservation manager in a significantly humanised world should not be the equilibrium of a pristine ecosystem but the resilience of biotic communities exposed to severe economic pressures.

\footnotetext{
${ }^{8}$ Holling (1973, p. 17).

${ }^{9}$ Holling (1973, p. 21).
} 
In contrast, Holling's perspective seeks to open up a management approach capable of sustaining productivity even under conditions of extreme instability. Its ability to adapt to and deflect from particular limits derives from the fact that it has abandoned long-term expectations:

A management approach based on resilience $[\ldots]$ would emphasize the need to keep options open, $[\ldots]$ and the need to emphasize heterogeneity. Flowing from this would be not the presumption of sufficient knowledge, but the recognition of our ignorance: not the assumption that future events are expected, but that they will be unexpected. The resilience framework can accommodate this shift in perspective, for it does not require a precise capacity to predict the future, but only a qualitative capacity to devise systems that can absorb and accommodate future events in whatever unexpected form they may take. ${ }^{10}$

The above passage, taken from the conclusion of Holling's 1973 article, is significant because it so clearly anticipates the guiding ideas of contemporary complex systems theory and its practical applications in crisis response. Under the sign of resilience, this is an approach to risk management which foregrounds the limits to predictive knowledge and insists on the prevalence of the unexpected, seeking to 'absorb and accommodate future events in whatever unexpected form they may take'.

Holling's later contributions to the practices of adaptive ecosystem management earned him a wide professional following. Following consensus-building work with senior neoclassical economists, Holling and fellow ecologists formed the Resilience Alliance and conceived of an ambition to expand the insights of the resilience perspective well beyond ecology. ${ }^{11}$ Emblematic in the name change of the house journal from Conservation Ecology to Ecology \& Society, the Alliance was no longer concerned with resilience as a property of ecosystems but of the coevolution of societies and ecosystems as a single system. This new research into 'social-ecological resilience' aspires to set the ground rules for a general systems theory capable of integrating society, the economy, and the biosphere. This totality is dubbed the 'Panarchy':

${ }^{10}$ Holling (1973, p. 21).

${ }^{11}$ Arrow, K., Bolin, B., Costanza, R., Dasgupta, P., Folke, C., Holling, C.S., Jansson, B., Levin, S., Mäler, K., Perrings, C. \& Pimentel, D. (1995). Economic growth, carrying capacity, and the environment. Ecological Economics, 15(2), 91-95. 
the structure in which systems, including those of nature (e.g., forests) and of humans (e.g., capitalism), as well as combined human-natural systems (e.g., institutions that govern natural resource use such as the Forest Service), are interlinked in continual adaptive cycles of growth, accumulation, restructuring, and renewal. ${ }^{12}$

There is a significant difference in scope and tone between this later definition of socio-ecological resilience and Holling's earlier work. Holling is no longer arguing that some ecosystems may not recover from extreme fluctuations, nor that ecosystems under the stress conditions of maximum sustained yield might be better preserved with a more 'resilient' management approach, but rather that all social-ecological system dynamics can be approached as non-linear iterations of an 'adaptive cycle', in which four distinct phases can be identified.

Where classical ecology focussed only on the phases of rapid successional growth $(r)$ followed by the conservation phase of a stable climax equilibrium $(\mathrm{K})$, the Resilience Alliance argue that these phases are inevitably followed by collapse $(\Omega)$ and then a spontaneous reorganisation that leads to a new growth phase $(\alpha)$ [see Fig. 14.1].

What unites these diverse systems and allows Holling to propose a common theorisation of their dynamics is the proposition that each can be defined by a concept of 'capital'. This capital, be it financial, organisational, or biophysical, is 'the inherent potential of a system that is available for change, since that potential determines the range of future options possible'. ${ }^{13}$ In short, Holling seeks to independently theorise an abstract dynamics of capital accumulation, one not predicated on the progressive temporality of classical political economy but rather on the inherent crisis tendencies of complex adaptive systems. In this respect Holling's later work becomes much more closely aligned with Hayek's mature theory of spontaneous market order and complex social evolution. Although Holling never cited Hayek, and Hayek routinely ignored the environmental sciences, I argue that it is Hayek's influential philosophy of free market dynamics that has made the contemporary policy arena so receptive to the overtures of the Resilience Alliance. If the Mont Pèlerin Society (MPS) and the Resilience Alliance have anything in common, it is the attempt to

\footnotetext{
${ }^{12}$ Gunderson, L. \& Holling, C.S. (Eds.) (2002). Panarchy: understanding transformations in human and natural systems. Washington, DC: Island Press.

${ }^{13}$ Holling, C. S. (2001). Understanding the complexity of economic, ecological and social systems. Ecosystems, (4), 390-405.
} 


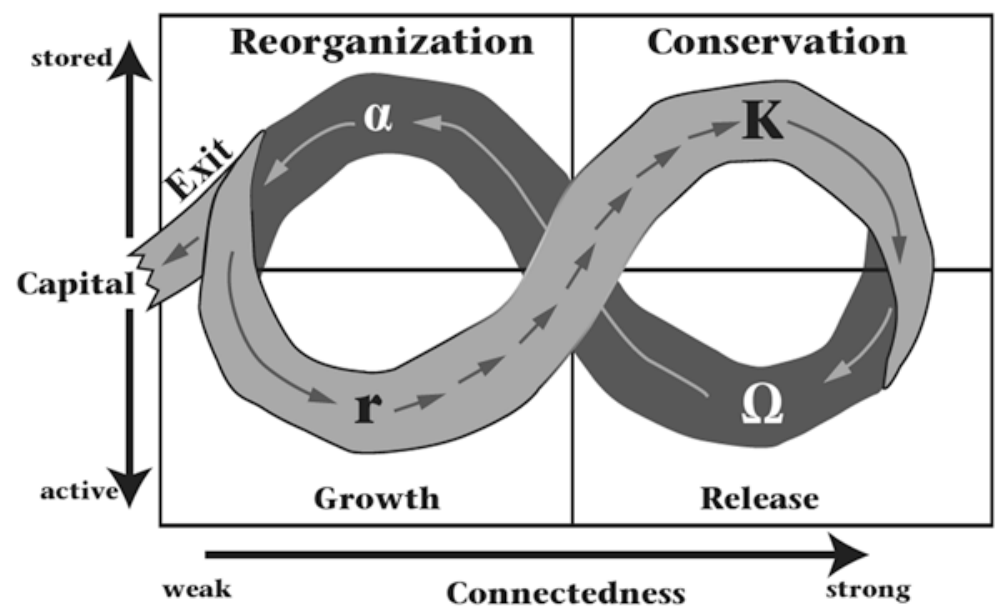

Fig. 14.1 Resilience as 'capital': the inherent potential of a system available for change. (Source: Panarchy, by Lance Gunderson \& C.S. Holling. Copyright (C) 2002 Island Press. Reproduced by permission of Island Press, Washington, DC)

forge a broad transdisciplinary philosophy capable of unifying nature and society under a single set of all-encompassing concepts.

\section{Hayek's Legacy: The Market as a Complex Ecological System}

It was once common for the academic and activist imagination to conflate and critique neoliberalism as the radical generalisation of neoclassical equilibrium theory to all aspects of social life. Yet as Mirowski and Plehwe have amply documented in their history of the 'neoliberal thought collective', the various scholars associated with the Mont Pèlerin Society (MPS) were at times internally split between the followers of the positivist Chicago School approach of Gary Becker, George Stigler, and Milton Friedman and the advocates of the ultra-subjectivist philosophy of the Austrian school, most famously associated with Friedrich Hayek. ${ }^{14}$

\footnotetext{
${ }^{14}$ Mirowski, P. \& Plehwe, D. (Eds.) (2009). The road from Mont Pèlerin: the making of the neoliberal thought collective. Cambridge, MA: Harvard University Press.
} 
In his early work, Hayek defended equilibrium as the constitutional metaphor of economic science, arguing in 1931 that if we want to explain economic phenomena at all, we have no means available but to build on the foundations given by the concept of a tendency towards an equilibrium'. ${ }^{15}$ By the late 1930s, the signs of his later dissent were becoming visible, as he developed a critique of rational economic planningwhich socialists such as Oskar Lange argued could by computationally grounded in Walrasian equilibrium theory-on the basis of the inherent limits to foresight and anticipation. ${ }^{16}$ In 'The Use of Knowledge in Society' (1945), Hayek argued for the impossibility of 'central planners' to arrive at their goals by attempting to eliminate, influence, or control prices for rational planning purposes. Only the floating prices constituting 'the market', a radically decentralised computation and signalling system, are able to discover the relative value of things, to adjust, evolve, and incorporate information held by isolated and differentiated individuals. Importantly, "these adjustments are probably never "perfect" in the sense in which the economist conceives of them in his equilibrium analysis'. ${ }^{17}$

The notion of price formation as distributed computation led Hayek to his mature unified theory of spontaneous order and social evolution, first suggested in his 'Theory of Complex Phenomena'. ${ }^{18}$ By the 1980s, he had abandoned the equilibrium analysis of his early career as a 'normal science' economist. Acknowledging that equilibrium analysis permitted the idea that planning was possible, he criticised the Keynesian state for seeing the economy as a hydraulic machine, a 'suction pump' operating on aggregate balances of supply and demand contained in a system of pipes and tanks. ${ }^{19}$ Remarking on the sheer complexity of the capital structure, he spoke of multiple 'streams' of value, ebbing and flowing into a river of liquid capital, constantly re-adjusting the production process, coursing down an

${ }^{15}$ Hayek, F. (1931). Prices and production. London: Routledge \& Kegan Paul, pp. 34-35.

${ }^{16}$ Lange, O. (1938). On the economic theory of socialism. Minneapolis: University of Minnesota Press; Lange, O. (1949). The practice of economic planning and the optimum allocation of resources, Econometrica (17), 166-171; Hayek, F. (1937). Economics and knowledge. Economica, 4(13), 33-54.

${ }^{17}$ Hayek, F. (1945). The use of knowledge in society. American Economic Review, 25(4), 519-530.

${ }^{18}$ Hayek, F. (1967). The theory of complex phenomena. In: Studies in philosophy, politics and economics (pp. 22-42). London: Routledge \& Kegan Paul.

${ }^{19}$ Caldwell, B. (2004). Hayek's challenge: an intellectual biography of F. A. Hayek. Chicago: University of Chicago Press, p. 226. 
ever-changing river bed..$^{20}$ In the 1950s, Hayek had mounted a subjectivist critique of the errors of 'scientism', exemplary of which were 'the various forms of social "energetics" which, from [...] Ernest Solvay, Wilhelm Ostvald and F. Soddy down to our own day have constantly reappeared among scientists and engineers when they turn to the problems of social organization'. ${ }^{21}$ In his late career, however, Hayek claimed natural science foundations for his own theory of spontaneous order, aligning his project with 'autopoesis, cybernetics, homeostasis, spontaneous order, synergetics, systems theory' and claiming the far-from-equilibrium thermodynamics of Ilya Prigogine as support for his work. ${ }^{22}$ In his final book, Hayek wrote:

$[\ldots]$ the extended order is perfectly natural, in the sense that it has itself, like similar biological phenomena, evolved naturally in the course of natural selection. $^{23}$

In 1974, Hayek was awarded the 'Nobel' economics prize, an event that signalled the changing fortunes of the Mont Pèlerin Society and terminated his long exile from academic respectability. In the speech he delivered for the occasion, 'The Pretence of Knowledge' (1974), Hayek not only gave voice to his enduring hostility to the state-engineered equilibria of the Keynesian welfare state but also to his dissatisfaction with the equilibrium models favoured by neoclassical economists, including the Chicago school neoliberals. ${ }^{24}$

Hayek's speech focused on the crises of the early 1970s-oil shocks, stagflation, third world and worker militancy-and the various efforts to intervene in them by expanding the regulatory arena of government. These crises, he contended, were symptoms of the intellectual failure of Keynesianism. He was therefore highly sceptical of efforts to respond to

${ }^{20}$ Hayek, F. (1981, Jan 27). The flow of goods and services. Address to the London School of Economics, published in German: (1984) Der strom und der güter und leistungen. Tübingen: Mohr Siebeck.

${ }^{21}$ Hayek, F. (1955). The counter-revolution of science. New York: Free Press, p. 51.

${ }^{22}$ Hayek, F. (1988). The fatal conceit: the errors of socialism-collected works of F.A. Hayek, vol. 1. London: Routledge, p. 9; Hodgson, G. (1994). Hayek, evolution and spontaneous order. In P. Mirowski (Ed.), Natural images in economic thought: markets read in tooth and claw (pp. 409-447). Cambridge: Cambridge University Press.

${ }^{23}$ Hayek (1988, p. 19).

${ }^{24}$ Hayek, F. (1974, Dec 11). The pretence of knowledge. Acceptance speech upon the award of the Sveriges Riksbank Prize in Economics in Memory of Alfred Nobel. Salzburg. 
them through techniques of state intervention which, he believed, had engendered them in the first place. Such interventions, Hayek intoned, were at best doomed to failure. The natural complexity of market phenomena was such that no centralised authority could hope to predict, much less control, the precise evolution of individual elements in the system. At worst, such efforts risked inducing long-term crises that would not have occurred without the undue interference of government. Hayek's critique of Keynesian and neoclassical equilibrium theories went well beyond the political sphere. What was at stake for him is no less than a thorough rethinking of epistemology itself. As a counter-argument to the predictive fantasies he saw as integral to the post-WWII Keynesian consensus, Hayek espoused an epistemology of limited knowledge and uncertain futures. 'I confess that I prefer true but imperfect knowledge, even if it leaves much indetermined and unpredictable, to a pretence of exact knowledge that is likely to be false. ${ }^{25}$

Hayek immediately put this imperfect yet superior epistemic position to good use, repudiating the claims of the nascent environmental movement and the landmark Report to the Club of Rome. The report included Keeling's curve measuring the rapid accumulation of atmospheric carbon dioxide and predicted that exponential growth would catastrophically undermine the regenerative capacities of the biosphere in the absence of a 'controlled, orderly transition from growth to global equilibrium'. ${ }^{26}$ Hayek denounced it as exemplary of the hubris of predictive modelling in the face of unknowable complexity:

The enormous publicity recently given by the media to a report pronouncing in the name of science on The Limits to Growth, and the silence of the same media about the devastating criticism this report has received from the competent experts, must make one feel somewhat apprehensive about the use to which the prestige of science can be put. ${ }^{27}$

${ }^{25}$ Hayek (1974).

${ }^{26}$ Meadows, D. et al. (1972). The limits to growth: a report for the Club of Rome's project on the predicament of mankind. New York: Universe Books, p. 71 \& p. 84.

${ }^{27}$ Hayek (1974). Hayek cited but two 'competent experts', who were not scientists but economists: Gottfried Haberler (MPS), a fellow student of von Mises then working for the (Atlas-affiliated) American Enterprise Institute, and Atlas fellow-traveller Wilfred Beckerman of Balliol College, Oxford, who assured us as holder of the 'second oldest chair in Political Economy' (first occupied by Nassau Senior) that although 'life on this Earth is very far from perfect there is no reason to think that continued economic growth will make it any worse'. Georgescu-Roegen begins his classic 1975 essay by citing Beckerman thus, with incredulity. 
Hayek's drastic critique was informed by a comprehensive ontology, one which would increasingly borrow from complex systems theory. Social systems, Hayek now claimed, are like the biological systems newly defined by scientists as complex, adaptive, and non-linear. They are not subject to quantification or prediction on the basis of the physical laws that govern the well-characterised systems of classical mechanics and thermodynamics (e.g. heat engines).

While in the physical sciences [...] any important factor which determines the observed events will $[\ldots]$ be directly observable and measurable, in the study of $[\ldots]$ complex phenomena such as the market, $[\ldots]$ the circumstances which will determine the outcome of a process [...] will hardly ever be fully known or measurable. ${ }^{28}$

Hayek went on to observe that '[it is] almost impossible for the layman, to distinguish between legitimate and illegitimate claims advanced in the name of science'-an insight which has since been put to great effect by the Atlas Network in undermining 'the prestige of science' through the mass dissemination of anti-environmental 'business propaganda'.

In rejecting the legacy of classical physics, Hayek's texts of the later 1970s and 1980s deploy an approach to complex adaptive systems that is formally very similar to Holling's but much more radical in its conflation of the financial, social, and biological spheres. Like all ontologies, Hayek's complexity turn generates a number of normative consequences. Reflecting the heritage of Herbert Spencer's ultra-libertarian evolutionism, it assumes that time's arrow moves ever in the direction of greater complexity: evolution occurs spontaneously in far from equilibrium conditions. Perturbations of greater or lesser force are not only inevitable, they are also necessary to the creativity of spontaneously organised complexity. This is a philosophy that does not so much reject natural law as redefine it in immanent, evolutionary terms, as that which is continually created anew and selected by the very exercise of market freedom:

Like scientific theories, [rules of conduct] are preserved by proving themselves useful, but, in contrast to scientific theories, by a proof which no one

Haberler, G. (1974). Economicgrowth and stability. Los Angeles: Nash; Beckerman, W. (1974). In defence of economic growth. London: Cape; Georgescu-Roegen, N. (1975). Energy and economic myths. Southern Economic Journal, 41(3), 347-381.

${ }^{28}$ Hayek (1974). 
needs to know, because the proof manifests itself in the resilience and progressive expansion of the order of society which makes it possible. [my emphasis $]^{29}$

Whilst Hayek defines the radical freedom of the market by its indifference to all external limits and laws, he also endows the market itself with immanent law-making powers, to which he then subjects the state. The laws of the market rest on no pre-existing foundation: their very resilience serves as proof of concept, in much the same way as the law of natural selection constantly proves or disproves the viability of chance mutations in nature. On a purely ontological level, Hayek places the immanent laws of market freedom prior to those of the state as an intentional law-making power. In historical terms, however, he recognises that the global order of market freedom has yet to be fully realised. This is a project of constitutional reform which would involve the radical remaking of all law and institutions in accordance with the allegedly 'self-organising' dynamic of the market, a project for which Hayek characteristically enrols the coercive powers of the state, even in its most authoritarian expressions.

\section{Complex Systems, Resilience, and Financial Risk Management}

It was once easy to dismiss Hayek's late philosophy as an intellectually interesting but politically inconsequential episode in the convoluted history of neoliberal economic thought. Chicago school neoliberals, including Milton Friedman, routinely derided their Austrian counterparts as too hermetic and subjectivist to deliver any practical dividends in the field of economics. Yet as complex systems theory has itself developed a repertoire of practical methodologies, the force of Hayek's late Austrian philosophy has come into its own, moving beyond the circles of the Santa Fe Institute and the Cato Institute to offer itself up, in the wake of the financial crisis of 2007, as a method of financial risk management. In 2006, the Federal Reserve Bank of New York hosted a conference exploring the usefulness of ecological models for rethinking the dynamics of risk in modern financial markets. Noting that 'systemic risk' in the financial system bears a strong resemblance to the dynamics of complex adaptive systems in the

\footnotetext{
${ }^{29}$ Hayek, F. (1978). The errors of constructivism. New studies in philosophy, politics, economics and the history of ideas (pp. 3-22), Chicago: University of Chicago Press.
} 
biophysical world, the conference report concluded that 'approaches to risk management in natural and physical systems could be pertinent to financial risk management'. ${ }^{30}$ Resilience was singled out as the watchword for new models of adaptive risk management sensitive enough to cope with the systemic risks of deregulated finance.

As the global financial crisis deepened, central bankers and financial risk managers increasingly turned to the resources of complex systems theory. In 2008, a group of leading ecologists including Robert May (at the time an advisor to the Bank of England) published a paper in Nature which offered the insights of complex ecological systems as a model for bankers during the gathering financial crisis. ${ }^{31}$ Andrew Haldane, executive director for financial stability at the Bank of England, was a vocal champion of this complexity turn. In a widely reported paper, he pointed to parallels between the epidemic of the SARS virus and the contagion effects of the collapse of Lehman Brothers:

Both events were manifestations of the behaviour under stress of a complex, adaptive network. Complex because these networks were a cat's-cradle of interconnections, financial and non-financial. Adaptive because behaviour in these networks was driven by interactions between optimizing, but confused, agents. Seizures in the electricity grid, degradation of ecosystems, the spread of epidemics and the disintegration of the financial system-each is essentially a different branch of the same network family tree. ${ }^{32}$

Pointing to the limitations of stress-testing, with its focus on 'tame' risk and normal distributions, Haldane suggested that financial risk managers should instead look to the strategies of non-predictive futurology (scenario planning) and adaptive anticipatory risk management deployed in the field of ecological management.

To insist on the Austrian influence in the inner sanctums of the world's leading financial institutions and their regulators may seem

\footnotetext{
${ }^{30}$ Kambhu, J., Weidman, S. \& Krishnan, N. (2007). New directions for understanding systemic risk: a report on a conference co-sponsored by the Federal Reserve Bank of New York and the National Academy of Sciences. Washington D.C.: National Academies Press, pp. 5-7.

${ }^{31}$ May, R., Simon Levin, S. \& Sugihara, G. (2008). Complex systems: ecology for bankers. Nature (451), 893-895.

${ }^{32}$ Haldane, A. (2009). Rethinking the financial network. Speech delivered at the Financial Students Association, Amsterdam, Bank of England.
} 
counter-intuitive. It is more commonly held that the reigning influence on financial risk and price modelling lies not in Hayek's hermetic philosophy but in neoclassical finance: Friedman's 'rational speculators', ArrowDebreu securities, the Efficient Market Hypothesis, the standardised algorithms of portfolio management software, and the central banker's Computable General Equilibrium Model-all of which presume the formal calculability of relevant states of risk. Again, however, we would contend that a de facto 'division of labour' has established itself between the formalism of equilibrium models, lending the imprimatur of rational calculation to the design of derivative trading instruments, and the Hayekian cosmology of complex systems theory, which both informs a macroeconomic vision of market dynamics in general and, in more recent times, justifies the implementation of new crisis response strategies at the institutional level. What unites both camps is the insistence that the distributed computation of the market always surpasses the state's ability to process information, the neoliberal creed that had licensed the progressive dismantling of the banking reforms legislated in the wake of the crisis of 1929 and the Great Depression.

Knowingly or not, advocates of the complexity turn in financial risk management share Hayek's epistemology of limited foresight. The predictability of future states of the world is, for them, not only an empirical but also a logical impossibility. What is distinctive about the interventions of Haldane and others is the fact that complex systems theory no longer functions for them as an argument against regulation, as it was for Hayek, but as the starting point for a reform of financial risk management, involving the systematic introduction of non-predictive, futurological methods of vulnerability analysis such as scenario planning. In the words of Nout Wellink, President of the Netherlands Bank and Chairman of the Basel Committee on Banking Supervision, 'the goal of regulatory changes should not be to decrease complexity per se, or to return to the financial regulations of the past, but to make complexity more manageable, by constraining systemic risk, and improving the resilience of the financial system as a whole'. ${ }^{33}$ It is more than ironic that the influence of the later Hayek should be making itself felt within the walls of the central bank-an institution whose pretensions to centralised knowledge were much maligned by the Austrian neoliberals.

\footnotetext{
${ }^{33}$ Wellink, N. (2009, Nov 10). Managing complexity. Speech given to the NautaDutilh seminar, Bussum.
} 
The global financial crisis played something like the triggering role that 9/11 represented for security, pushing new methods of futurology, contingency planning, and crisis response onto the policy reform agenda, testament to the growing respectability of the resilience perspective as a framework of crisis management.

\section{Resilience in US National Security: Critical Infrastructure Protection and the Culture of Preparedness}

'Resilience' has become ubiquitous as an operational strategy of national security, emergency preparedness, and crisis response. Although by no means absent prior to 2001 or restricted to the US prosecution of the war on terror, the term has proliferated since the establishment of the US Department of Homeland Security (DHS) in 2002 under President George W. Bush. The National Strategy for Homeland Security, published in 2002 and reissued in 2007, brought together the structural resilience of 'critical infrastructures' with the 'operational resilience' of emergency response organisations, government institutions, and private enterprises in the face of crisis. Identifying 'resilience' as the essence of a 'culture of preparedness', it situated its recommendations within a general recognition of the limits to preparation.

Despite our best efforts, achieving a complete state of [...] protection is not possible in the face of the numerous and varied catastrophic possibilities that could challenge the security of America today. [...] we cannot envision or prepare for every potential threat, we must understand and accept a certain level of risk as a permanent condition. ${ }^{34}$

These 'catastrophic possibilities' span the divide between military and civil threats, encompassing terrorist attacks, natural disasters, climate change, and infectious disease in a non-exhaustive 'full-spectrum' list of contingencies. The strategy is notable for insisting that none of these threats are fully preventable, proposing instead the notion of 'resilience' as a default condition of emergency response.

\footnotetext{
${ }^{34}$ Department of Homeland Security (2007, Oct). The national strategy for homeland Security. www.dhs.gov/xabout/history/gc_1193938363680.shtm.
} 
In US security policy discourse, the concept of resilience was first deployed in a 1981 proposal to the Federal Emergency Management Agency (FEMA) for a fully decentralised renewable energy grid. ${ }^{35}$ During the administration of President Carter, alternative energy development enjoyed federal support, but this was reversed by the Reagan administration. The defence of critical infrastructure as an area of government interest began to crystallise under President Clinton. In 1996, the President's Commission on Critical Infrastructure Protection defined critical infrastructure as national utilities so vital 'that their incapacity or destruction would have a debilitating effect on the defence or economic security of the United States'. ${ }^{36}$ It is significant that the emergence of critical infrastructure as a national security concern took place during a period of intense (re)privatisation of formerly public infrastructure services, a move that created an opportunity for secondary financial markets specialising in the income streams (or securitised debts) arising from infrastructure privatisation itself. The categorisation of critical infrastructure protection as a national security concern signalled an at least tacit recognition that the financial and civil risks generated by the widespread privatisation of vital national services could themselves be construed as a significant threat to civil defence. As an optic for assessing and responding to risk, critical infrastructure protection blurs the boundaries between the properly military threat of terrorist attack and civil contingencies such as natural disaster, operational accidents, the failure of financial systems, or civil protest. This strategic conflation of previously separate spheres of action would be institutionalised under the administration of George W. Bush, when both FEMA and the Environmental Protection Agency would be absorbed into the Department of Homeland Security (DHS). At stake in this process of reform was not merely the deregulation of formerly state-controlled services and networks but the transfer of regulatory authority from the civil sectors of public transport, health and safety, environmental protection, and emergency response to a logistics and security sector newly organised around counter-terrorism.

\footnotetext{
${ }^{35}$ Lovins, A. \& Lovins, L. (1981). Energy policies for resilience and national security. San Francisco: Friends of the Earth.

${ }^{36}$ Lopez, B. (2006). Critical infrastructure protection in the United States since 1993. In P. Auerswald et al. (Eds.), Seeds of disaster, roots of response: how private action can reduce public vulnerability (pp. 37-50). Cambridge: Cambridge University Press.
} 
The National Security Strategy (NSS) of 2007 reasserted the importance of 'resilience' as both a strategic and psychological imperative of national preparedness and more fully incorporated the ecosystemic and financial dimension of crisis into its taxonomy of contingencies. Between the 2002 and 2007 editions of the NSS, Hurricane Katrina had intervened, blurring further the cognitive distinctions between the unpredictable terrorist threat, financial crisis, and environmental disaster. The 2007 NSS combined an almost obsessive focus on the necessity of preparedness with the disarming recognition that anticipation and prevention of future contingencies is a logical impossibility. Within this optic, 'preparedness' demands a generic ability to adapt to unknowable contingencies rather than actual prevention or indeed adaptation to future events of known probability. As in the work of the later Hayek, the catastrophic event here becomes a sign not of the occasional failure to predict, prevent, and manage crisis but of the allegedly ontological limits to public management and the impossibly of state planning for social security. What was called for instead is a 'culture' of resilience that turns crisis response into a strategy of permanent, open-ended responsiveness, integrating emergency preparedness into the infrastructures of everyday life and the psychology of citizens. It is notable that the culture of preparedness envisaged by the Department of Homeland Security sees no end point to emergency. The strategy of resilience replaces the short-term relief effort-with its aim to restore the status quo through post-catastrophe reconstruction-with a call to permanent adaptability in and through crisis. What is resilience, after all, if not the acceptance of disequilibrium itself as a principle of organisation? The permanentisation of crisis response leads to another consequence-the blurring of the boundaries between crisis response, post-catastrophe reconstruction, and urban planning. With Friedman, the DHS lost no time in asserting that climate disasters such as Hurricane Katrina should be seized upon as opportunities for the selective transformation of urban space- a recommendation heeded all too well in the subsequent 'regeneration' of New Orleans, with its selective exclusion of the African-American poor. 


\section{Resilient Urbanism, Post-developmental Growth, AND ECOlOgical SECURITY}

If 'resilience thinking' has effectively pervaded the institutional logic and operational procedures of homeland security in the United States, the conflation of security, environmental disaster response, and critical infrastructure protection under the rubric of resilience should not be accounted as an aberration of US exceptionalism. There exists a real tension between the various factions pushing the policy agenda of resilience in its different aspects (environmentalists vs security interests) and between the precautionary and pre-emptive perspectives on resilience (the European Commission as opposed to the United States); it would be simplifying things to distribute these differences along national fault lines. Such divisions are complicated by the transnational networks of scientific and economic expertise informing institutions such as the Stockholm Resilience Centre, a significant node of contact between the academic world of environmental science and the policy-making world of international development organisations, where multilateral climate agreements and environmental conventions are forged.

Responding to the criticisms of social movements and NGOs, during the 1990s, institutions such as the World Bank, the IMF, and the United Nations rallied around the ethos of 'environmentally sustainable development'. The monolithic industrial modernisation projects of the postWWII era, designed to replace subsistence agriculture with large export industries, were now discredited by their all too evident environmental costs. The World Bank began hiring environmental NGOs as project consultants and found a new role for itself in using its role as creditor to leverage debtor-state reforms supporting the internationalisation of conservation along neoliberal lines, 'developing' shifting cultivators into park rangers and eco-tour operators while recasting projects such as hydroelectric dams as supporting environmental sustainability. This has occurred in tandem with calls for the 'securitization of the biosphere': the privatisation and trading of the flow of 'ecosystem services' maintained by intact ecosystems, in recognition that rainforests and watersheds are critical 'natural infrastructure assets' that must to be priced in financial markets in order that corporations can 'capture the value' of biodiversity 
conservation. ${ }^{37}$ As institutions have begun to recognise the intensifying socio-economic effects of global heating and ecosystem losses, we have seen a rapid uptake of the adaptive model of resource management offered by resilience science.

The Stockholm Resilience Centre, directly inspired by the work of Holling, serves as a mediator between the theorists of socio-ecological resilience and global development organisations. It performs the work of scaling up and standardising the principles of adaptive management for use in the field. Through this translational work, resilience science as a largely theoretical proposition has become fully operative as a methodology of micro and macro resource management. Yet the Stockholm Resilience Centre aspires to be much more than a platform for the strictly environmental uses of resilience science. Through its publications in journals, symposia, reports, consultancies, and collaborations with international institutions, it also shows ambition to furnish a general systems theory of 'socio-ecological governance' of direct use to policy-makers in the field of development economics.

The international development and environment projects now couched in the language of resilient urbanism are legion. The United Nations advocates the concept of an ecosystem-based approach to the management of urban environments. Operating on the principle that environmental management, urban planning, and infrastructure renewal must be pursued simultaneously, projects in urban regeneration and anticipatory reconstruction outlined by the UN and by the Rockefeller Foundation explicitly invoke the Hollingian principles of adaptive management and resilient infrastructure. A rural development programme co-sponsored by the United Nations Development Programme, United Nations Environment Programme, the World Bank, and the World Resources Institute is even more explicitly indebted to the principles of resilience science, outlining an ambitious model of post-developmental, post-industrial growth financed by payments to rural communities for the maintenance of ecosystem services. In a report entitled 'Roots of Resilience', the ideological project of socio-ecological resilience is summarised in the most succinct of terms:

${ }^{37}$ Chilchilnisky, G. \& Heal, G. (2000). Securitizing the biosphere. In G. Chilchilnisky \&. G. Heal (Eds.), Environmental markets (pp. 169-179). Columbia University Press. 
Resilience is the capacity to adapt and to thrive in the face of challenge. This report contends that when the poor successfully (and sustainably) scale-up ecosystem-based enterprises, their resilience can increase in three dimensions. They can become more economically resilient-better able to face economic risks. They-and their communities_can become more socially resilient-better able to work together for mutual benefit. And the ecosystems they live in can become more biologically resilient-more productive and stable. ${ }^{38}$

In the vision of a post-developmental future offered by these various projects, financial and ecological crises stand in a relationship of mutual determination. The resilient community is better able to weather its chronic exposure to global financial markets through the adoption of a localised, decentralised, post-carbon, ecosystems-based model of growth. Building up resilience to the intensifying climate crisis is not merely analogous to coping with recurrent financial shocks, it is also the means through which economic and social resilience is to be achieved. This is a tacit recognition that 'development' for the post-colonial poor no longer consists in achieving the first-world standards of urban affluence promised by W.W. Rostow's modernisation theory but in merely surviving, preferably on the land instead of the slums, the after-effects of industrial development and the financial conditions imposed by the Washington consensus.

There is a strong selective dimension to the contemporary doctrine of resilient growth, one that both reiterates and modifies the Darwinian law of natural selection. Relying as it does on the non-equilibrium dynamics of complex systems theory, what the resilience perspective demands is not so much progressive adaptation to a continually reinvented norm as permanent adaptability to extremes of turbulence. In this context, the appeal to ecological security is often invoked as a means of distinguishing those who are sufficiently resilient to survive as dignified participants in a globally integrated world from those who are not resilient enough. Thus Holling's later work, relayed by his associates in the Stockholm Resilience Centre, offers a classificatory schema of socio-economic adaptability in which various types of maladaptation can be distinguished. There are those societies that can be compared to depleted ecosystems, whose resilience has been so

${ }^{38}$ United Nations Development Programme, United Nations Environment Programme, World Bank, World Resources Institute (2008). World resources 2008: roots of resiliencegrowing the wealth of the poor. Washington, DC: World Resources Institute. 
thoroughly eroded that there is no longer any scope for reorganisation. ${ }^{39}$ But there are also those societies that have become so internally integrated that they are now too resistant to perturbation-unable to change in the face of shocks that can be as creative and generative as they are destructive. 'Rigidity traps' occur when 'maladaptive' regimes with 'large bureaucracies' inhibit the chaotic creativity of complex systems evolution. As in Hayek's political philosophy of a fully decentralised liberalism, the morality tale of resilient growth routinely invokes the totalitarian socialism of the Soviet Union as cautionary counter-example. Increasingly articulated within a discourse of 'ecological security', the threat represented by the non-resilient society is routinely linked to the fear of migration. The authors of Roots of Resilience, for example, offer the following ominous reflections on the failure to adapt to climate change:

$[\ldots]$ in the coming decades, the rural poor will be tested as the impacts of climate change manifest. There are no cities in the developing world large enough or wealthy enough to absorb the migration of the poor who have no buffer against these dangers and can find no means to adapt. The political and social instability inherent in such potentially massive movements of people is of increasing concern to the international community. [...] The consequences of not acting may well test the depths of compassion. ${ }^{40}$

The consequences of this logic, of course, go well beyond the arena of strictly environmental politics if, as we have suggested, the dynamics of a stressed biosphere have been rendered indistinguishable from those of world markets in contemporary security policy. Whether we look to the politics of 'sustainable development', the regulation of global finance, or the organised obstruction of climate policy, resilience risks becoming the measure of one's fitness to survive in the turbulent order of things. The criteria of selection may well have shifted. Yet in the last instance, and for all its flexibility, the resilience perspective is no less rigorous in its selective function than Darwinian evolution.

\footnotetext{
${ }^{39}$ Holling (2001, p. 400).

${ }^{40}$ UNDP, UNEP, WB, WRI (2008: ix).
} 


\section{Resilience as Abandonment: The Neoliberal Response to Planetary Crisis}

Complex systems theory, it should be remembered, grew out of libertarian, environmentalist, and often leftist critiques of the 'command and control' hubris of Cold War, first-order cybernetics. In this respect, the conceptual and political career of Holling's concept of 'resilience', developed as a reaction against the 'pathology' of top-down natural resource management, is exemplary. ${ }^{41}$ If second-order (or complex) systems theory was advanced by those who opposed the falsely omniscient, commanding vision of the Cold War state, it would appear that the new epistemological realism was achieved by re-absorbing critique into the workings of systems theory itself. The point is underscored in no uncertain terms by Niklas Luhmann, an advocate of complex systems theory as a rigorous sociological method. The complex social system, he remarks, 'feeds upon deviations from normal reproduction'; that is, it thrives upon disruptions to its own state of equilibrium. ${ }^{42}$ By metabolising critique into its internal dynamic, the complex adaptive system remains self-referential even when it encounters the most violent of shocks. It is for this reason, Luhmann concludes, that complex adaptive systems defy critique, forcing all wouldbe critics to inhabit the system they set out to challenge: 'The unity of the system is the self-reference of the system and its change will always require working within, not against the system. ${ }^{43}$

This logic is exemplified in the clearest of terms by the evolution of Holling's theory of resilience. Originally positioned as an ecological critique of the destructive consequences of orthodox growth economics - in his classic 1973 article Holling defined resilience as essentially 'concerned with the probabilities of extinction' ${ }^{44}$ - it has now moved to a position of subordinate collusion with an agenda of resource management which collapses ecological crisis into the 'creative' destruction of a truly Hayekian world order, one too complex and too far beyond equilibrium for any governing body to understand, predict, or regulate in the service of longterm social objectives, such as conserving the thermal and ecological

\footnotetext{
${ }^{41}$ Holling, C.S. \& Meffe, G. (1996). Command and control and the pathology of natural resource management. Conservation Biology, 10(2), 328-337.

${ }^{42}$ Luhmann, N. (1990). World society as a social system. In: Essays on self-reference (pp. 175-190). New York: Columbia University Press, p. 180.

${ }^{43}$ Luhmann (1990, p. 183).

${ }^{44}$ Holling (1973, p. 20).
} 
stability of the oikos upon which all our life depends. In the process, resilience has ceased to operate as a critique emphasising the fragility of complex communities of life. It now functions to naturalise neoliberal strategies of rule and to normalise the events of planetary catastrophe.

This is a post-environmentalist 'economy of nature' which finds its clearest expression in the counter-intuitive claim of Peter Kareiva, senior ecologist at the corporate conservation foundation The Nature Conservancy, that 'Nature is so resilient that it can recover rapidly from even the most powerful human disturbances' ${ }^{45}$ Recall that until the 1990s, the IMF maintained that 'macroeconomics has nothing to do with the environment'. ${ }^{46}$ In stark contrast to this early denialist position, and to Kareiva's equally denialist doctrine of the infinite resilience of ecological communities to destruction, an IMF paper released in 2019 reflected on 'a growing agreement between economists and scientists [that] the risk of catastrophic and irreversible disaster is rising, implying potentially infinite costs of unmitigated climate change, including, in the extreme, human extinction' ${ }^{47}$

For decades, the neoliberal political machine has mounted a counterscience campaign that defines the 'post-truth' era, railing against any effective decarbonisation strategy in the name of the 'free market'. Due to the efforts of engineers, large-scale renewable energy systems combining solar photovoltaics, wind turbines, and batteries now yield clean, dispatchable electricity at a lower cost than maintaining existing coal, nuclear, and gas generation assets in operation, even taking into account the perennial subsidies, indemnities, and general immunity from pollution taxes enjoyed by the thermal power sector. As the renewables revolution gathers momentum with movements for climate justice, financial markets are slowly responding to price signals and market sentiment by withdrawing investment and insurance from these catastrophically risky 'stranded assets'. As the free market begins to abandon the fossil fuel sector, certain voices within the Atlas Network have reciprocated, calling liberalism into question and discovering the virtues of conservative nationalism and

\footnotetext{
${ }^{45}$ Kareiva, P., Lalasz, R., \& Marvier, M. (2011). Conservation in the Anthropocene: beyond solitude and fragility. In: Love your monsters: post-environmentalism and the Anthropocene. Oakland: Breakthrough Institute.

${ }^{46}$ Daly, H. (1996). Beyond growth: the economics of sustainable development. Boston Beacon Press, p. 144.

${ }^{47}$ Krogstrup, S. \& Oman, W. (2019, Sept 4). Macroeconomic and financial policies for climate change mitigation. IMF Working Paper No. 19/185.
} 
nationalist industry policy—as Atlas chair Alejandro Chafuen (MPS) reports in a recent article. ${ }^{48}$ This is especially apparent in the fossil fuel sectors of hydrocarbon-rich jurisdictions such as the US, Brazil, Canada, and Australia. States have always underwritten the risky profitability of private fossil fuel extraction and energy distribution through tax holidays, direct subsidies from public revenue, and national security interventions: now neoliberals and industry lobbies are calling for all manner of bailouts, even nationalisations of fossil infrastructure. Increasingly, such states appear as the local legislative arm of fossil capital, as fossil lobbyists occupy administrations, sweep away 'green tape', and designate coal, oil, and gas projects as 'critical infrastructures' vital to the national security of the homeland. Stripped of its cosmopolitan and internationalist garb, neoliberalism appears ever more clearly as what it perhaps has always been at root: an authoritarian project to manage surplus life in terms of private interests invested in the extractive industries.

An exemplary case of the contemporary uses of resilience for the 'management' of ecological risk can be found in the Great Barrier Reef Foundation (GBRF), a publicly funded business 'charity' promising to 'build the resilience' of Australia's coral reef ecosystems in the wake of the unprecedented mass bleaching events of 2016-2018. According to the Intergovernmental Panel on Climate Change (IPCC), coral reefs are likely to decline by $70-90 \%$ with global warming of $1.5^{\circ} \mathrm{C}$, and more or less consigned to history with warming of $2^{\circ} \mathrm{C} .{ }^{49}$ The physical cause of coral reef destruction is of course well known. Mass bleaching events are the result of increasingly intense marine heatwaves-which kill the photosynthesising microbial symbionts at the basis of the coral reef food chain. ${ }^{50}$ The oceans have accumulated more than $90 \%$ of the vast quantity of heat gained by the planetary surface as a result of the combustion of fossil fuels. ${ }^{51}$ Marine ecosystems are also threatened by the acidification of the oceans through absorption of carbon dioxide from the atmosphere, which

\footnotetext{
${ }^{48}$ Chafuen, A. (2019, Aug 29). Business, the economy, and the new effort to enshrine nationalism. Forbes.

${ }^{49}$ IPCC (2018, Oct 28). Summary for policy makers of IPCC special report on global warming of $1.5^{\circ} \mathrm{C}$.

${ }^{50}$ Veron, J., Hoegh-Guldberg, O., Lenton, T., et al (2009). The coral reef crisis: the critical importance of < 350 ppm $\mathrm{CO}_{2}$. Marine Pollution Bulletin, 58(10), 1428-1436.

${ }^{51}$ Zanna, L., Khatiwala, S., Gregory, J., Ison, J. \& Heimbach, P. (2019). Global reconstruction of historical ocean heat storage and transport. Proceedings of the National Academy of Science, 116(4), 1126-1131.
} 
will increasingly prevent the formation of the calcium carbonates that comprise the skeletons of reef corals and other marine organisms, from shellfish to several classes of the photosynthesising phytoplankton which drive much of the global carbon cycle.

In response to public alarm at the coral reef crisis, in 2018 the Australian government of Liberal Prime Minister Malcolm Turnbull awarded an untendered grant of $\mathrm{A} \$ 444$ million to the GBRF, which was tasked with finding ways to 'boost reef resilience'. How, we might well ask, is this to be achieved? In its publicly funded public relations material-lavishly illustrated with images of healthy and abundant reefs, and not with dead acres of ghost-white corals - we are promised community engagement and education programmes, experimental studies in coral aquaculture and cryopreservation, and the development of wholly speculative geoengineering technologies. These include 'approaches to potentially decrease solar radiation on reefs (e.g. creating shade through clouds, mist, fog, or surface films)' and the prototyping of a 'Swiss army knife-style robot reef protector, the RangerBot Autonomous Underwater Vehicle'. Confusing marine ecosystem collapse with urban planning, the GBRF's Resilient Reefs Program promises to combine 'site-specific coral reef expertise [...] with learnings from the proven resilience-building model of the [Rockefeller Foundation's] 100 Resilient Cities initiative'. ${ }^{52}$ A huge coal and bauxite bulk transport vessel operated by Rio Tinto-described by the GBRF as a 'ship of opportunity'-has been fitted out with instruments to measure ocean acidification, as it sails past the reef on its ordinary business of contributing to ocean acidification. Whilst duly acknowledging the Paris Climate Treaty and the existential threats to coral reefs posed by global heating, at no point does the GBRF offer any support for the obvious conclusion, that the global collapse of marine ecosystem resilience can only be slowed, if at all, by a worldwide programme of rapid and permanent retrenchment of the fossil fuel sector.

Like chalk in acid, the apparent paradox dissolves when we learn that the board of the GBRF is composed of executives recruited from among the fossil fuel, mining, and other combustion-intensive corporations that, through business and industry associations, the Atlas-affiliated Institute for Public Affairs, a media dominated by Murdoch's News Corporation, and the governing Liberal-National Party, have effectively neutralised all

\footnotetext{
${ }^{52}$ Great Barrier Reef Foundation (2019). https://www.barrierreef.org/. Accessed 17 Dec 2019
} 
attempts to establish a national climate policy in Australia. Deservingly or otherwise, Australia in the past has been seen as a beacon of egalitarian democracy and international cooperation. Since the 1996 election of Liberal Prime Minister John Howard (inducted into the MPS in 2011), conservative governments have used Australia's vote in UN Framework Convention on Climate Change (UNFCCC) conferences to frustrate international climate agreements. This is a network of power which seems bent on constituting the coal and gas exporting equivalent of an authoritarian petro-state in a dry, hot continent increasingly vulnerable to the intensifying droughts and summer heatwaves of global heating, manifest in the wholly unprecedented bushfires of 2019-2020. At the time of writing, this unimaginable inferno has reduced a vast portion of the remnant eucalypt and rainforests of south-eastern Australia to ashes, a holocaust of livestock and perhaps a billion native animals, choking cities and towns with smoke-filled air and threatening their dwindling water supplies, burning thousands of houses, farms, and livestock, killing volunteer firefighters, and generating waves of internally displaced climate refugees, with hundreds of wildfires still burning out of control. Some seventeen million hectares are reported to have already burned, an area greater than that of England. The initial response of Liberal Prime Minister Scott Morrison to this unfolding climate emergency was to take a secret holiday in Hawaii, to deny that anything out of the ordinary was going on, and to extol the virtues of the national cricket team. When asked whether the bushfire crisis would prompt a rethink of his government's opposition to climate policy, Morrison replied: 'I think more significantly that resilience and adaptation need an even greater focus. [...] We must build our resilience for the future and that must be done on the science and the practical realities of the things we can do right here to make a difference. ${ }^{53}$ Fittingly, the chair of the GBRF board is a former chief executive of the Australian subsidiary of ExxonMobil-that global private empire synonymous not only with the Atlas Network's decades-long campaign of deception, science denial, and obstruction of climate policy but with the century-old neoliberal project to immunise 'the world economy' from democracy.

\footnotetext{
${ }^{53}$ Martin, S. (2020, Jan 14). Scott Morrison to focus on 'resilience and adaptation' to address climate change. The Guardian.
} 
Such is one version of the tragic history by which the Earth's inestimably beautiful, diverse and regenerative capacity for intergenerational abundance was exposed to a future of more heat than life, the legacy of a nomos that refuses the oikos, of an eschatology of infinite combustion beyond all limits of life, law, knowledge, and care. A world deep in ruin: as C.S. Peirce foretold, such are the consequences of a creed given to "the exaggeration of the beneficial aspects of greed [...]', of a philosophy in which 'greed is the great agent in the elevation of the human race and the evolution of the universe' ${ }^{54}$ The house, as the children born to the millennium see with terrifying moral clarity, is on fire. If there is anything for people of goodwill to strive together for, it is surely for a global Green New Deal capable of bringing the fossil-fuelled neoliberal era to a close. ${ }^{55}$ It must of course be admitted that the window of possibility for avoiding the unthinkable fate that the Earth sciences warned us of a lifetime ago seems ever more narrow. Yet there is certainly time enough remaining to us for the truth to be told and-it must resolutely be hoped-for justice to be done.

${ }^{54}$ Peirce, C. S. (1893). Evolutionary love. The Monist, 3(2), 176-200.

${ }^{55}$ See e.g.: Klein, N. (2019). On fire: the (burning) case for a Green New Deal. Simon \& Schuster. 